\title{
The U.S. National Efforts to Counter Domestic Terrorism: Progress and Controversy
}

\author{
Faruq Arjuna Hendroy \\ Centre for the Middle East and Global Peace Studies, UIN Syarif \\ Hidayatullah Jakarta
}

\begin{abstract}
The article examines the increasing domestic terrorism threat within the U.S. borders and how the U.S. government responded to it. The robust maneuver of the U.S. ledcoalition in the Middle East to coercively hunt down the terrorist groups does not fully stop them from posing the threat. Ironically, the terrorist groups direct their attacks to the U.S. homeland through their small networks. It is not difficult to build networks in the U.S. homeland, since the the advance of millennium technology enables them to radicalize people from long distance. The U.S. surely concerns about the increasing number of terrorist attacks within its borders, that it recently issued a set of national counter-terrorism strategy combining both coercive and soft approach. However, the approval of discriminatory and controversial travel ban policy was believed to hamper the existing national strategy, mistarget the main causes, and create new problems.
\end{abstract}

Keywords: The U.S. National Counter-Terrorism Strategy, Domestic Terrorism, Home-grown Terrorism, Coercive approach, Soft approach, Travel Ban Policy

Artikel ini membahas tentang peningkatan terorisme dalam negeri Amerika Serikat dan bagaimana pemerintah Amerika Serikat meresponnya. Manuver yang dilakukan oleh koalisi pimpinan Amerika Serikat di Timur Tengah yang secara koersif mengejar kelompok teroris tidak membuat mereka berhenti menebar ancaman. Ironisnya, justru sekarang mereka mengarahkan langsung ancamannya ke dalam negeri Amerika Serikat melalui jaringan-jaringan kecil mereka. Tidak sulit bagi mereka untuk membangun jaringan-jaringan tersebut karena adanya kemajuan teknologi milenium yang memungkinkan mereka untuk meradikalisasi seseorang dari kejauhan. AS tentu saja sangat khawatir dengan peningkatan jumlah serangan teroris di dalam negeri sehingga AS baru-baru ini mengeluarkan seperangkat strategi nasional yang menggabungkan pendekatan koersif dan lunak. Bagaimanapun, pengesahan kebijakan larangan perjalanan yang diskriminatif dan kontroversial dipercaya akan menjadi penghalang untuk strategi nasional yang sudah ada, tidak tepat sasaran, dan menciptakan masalah-masalah baru.

Kata kunci: Strategi Counter-terrorism Nasional AS, Terorisme Dalam Negeri, Terorisme Lahir Dari Dalam, Pendekatan Koersif, Pendekatan Lunak, Kebijakan Larangan Perjalanan 
Terrorism issue has become a concern in the United States since 9/11 tragedy. The United States has provenly implemented various strategies in countering terrorism issue. It started with Bush's administration. Soon after the horrible 9/11 tragedy, the United States drew a campaign of global war on terror and waged war with Taliban of Afghanistan in pursuit of Al-Qaeda, the accused perpetrator of 9/11 tragedy. Its invaded Afghanistan on 7 October 2001, to coercively remove Taliban from power. The plan met its objective when precisely on 9 December 2001, Taliban regime was entirely removed. Afterwards, the United States had open access to Afghanistan and enabled it to monitor Al-Qaeda easily (Katzman and Thomas 2017, 6-7). The U.S. coercive response toward terrorism continued under Obama's administration. The best military achievement is the successful assassination of Osama Bin Laden in 2011, despite there's no documentation proof (CNN 2018). The death of Osama didn't halt the U.S. from continuing its campaign on global war on terror, as a dangerous newborn terrorist group, Islamic State in Iraq and Syria (ISIS), appeared. ISIS dragged the U.S to Iraq and Syria with its total allies of 62 states across the globe, including the regional entities such as EU and Arab League to wage war with it. The US executed the similar strategy to combat the terror in Iraq and Syria with that of Afghanistan; carrying out the air-strike while engaging and empowering the local fighters to help in fight (Hendroy 2016, 48-50).

The U.S robust role in suppressing terrorism growth in the Middle East didn't guarantee the U.S homeland safety. Recent various attacks carried out by Muslim radicals endangered the U.S domestically. Surprisingly, most attacks were carried out by the terrorists who grew and got radicalized within the U.S., instead of the foreign terrorists who are sneaking into the borderline. The terrorist group has shifted its strategy following the setback caused by the U.S. coalition pressure, from inviting the followers to come to its daulah to ordering them to stay within their borders and carry out the sporadic revenge attacks therein. To combat the domestic terrorism threat, the U.S. issued an updated set of national counter-terrorism strategy meant to tackle the domestic terrorism threat. It combines between coercive and soft approach to successfully tackle the issue. This article is going to discuss the U.S. domestic terrorism phenomenon, its causes and strategies, and how the U.S. government responded through the release of the most updated set of national counter-terrorism strategy, indicating that the U.S. keeps improving its counter-terrorism efforts. This article also going to discuss a controversial policy responded by domestic and international protests, called travel ban policy, which was deemed contra productive to the existing national strategy and less safe rather than more.

\section{The U.S. Domestic Concern: Home-Grown Terrorism}

The United States is facing the increasing domestic problem related to terrorism issues for now. In the last few years, terrorism rapidly flourished within the U.S. borders. This phenomenon is commonly known as home-grown terrorism. According to Constitution on Acts to Prevent Home-grown Terrorism and for Other Purposes (2007), home-grown terrorism is:

\footnotetext{
"the use, planned use, or threatened use of force or violence by a group or individual born, raised, or based and operating primarily within the United States or any possession of the United States to intimidate or coerce the United States government, the civilian population of the United States, or any segment thereof, in furtherance of political or social objective."
}

Home-grown terrorism is usually associated with a global mission, even though it does not always mean that way. It needs to bear in mind that home grown terrorism is not 
appearing without reasons. The hatred is the key driving factor to its growth. With a bunch of hatred inside their hearts, the deviate doctrine and beliefs were enough to get them inspired, pulling them into axis of terrorism. Home grown terrorists usually share the similar characteristics; mostly male, young (below 35 years old), educated, lack of criminal records, and from the middle-class socioeconomic group (Minteh 2014, 3-4). In the U.S itself, 100 terrorist attacks in total are associated with Islamic radical movements since $9 / 11,87$ of them were carried out by home-grown terrorists after being radicalized at home (Inserra 2017).

The U.S. government paid high attention to Muslim immigrants since a few of them were responsible for terrorist attacks in the U.S. homeland. However, in case of radical immigrants, they were radicalized after residing in the U.S for a certain period of time, which means they were normal like others before entering the U.S. A few examples support this argument: (1) Akayed Ullah, a Bangladeshi national who plotted an attack New York's bus terminal in 2017, was radicalized in 2014 or three years after his entry to the U.S.; (2) Khaleed Ahmad, an Indian national, entered the U.S in 1998 and became radicalized in 2004; (3) Mufid Efgeeh, Yemeni national, became radicalized in 2013 when he was caught plotting the shooting of the U.S soldiers. He had been residing in the U.S since 1997; (4) Mahmoud Amin Mohammed Elhassan, from Sudan, was radicalized in 2015, while he entered the U.S in 2012 with his normal mindset; (5) Uzair Paracha, a Pakistani man, has resided in the United States since 1980 and just been radicalized 20 years later in 2005 , etc. The immigrants were not the only individuals who turned out to be the terrorists, since there were also several nativeborn Americans who became radicalized and carried out attacks within the U.S. borders (Levitt 2018).

Recently, ISIS has applied a shifting strategy following the setback and disengagement of some territories it once controlled caused by the U.S. coalition pressure. It called for the sporadic attacks in the U.S and its coalition's soils, marking the stimulus for the massive home-grown terrorism in the Western lands as a whole. A data from terrorism researcher Sam Mulin has shown that the significant increase of the terrorist attacks in the Western countries started to occur in 2014. Since then, the attacks multiplied in 2015,2016 , and so on. They were mostly carried out by ISIS-inspired Western individuals instead of foreign terrorists. Surprisingly, a report has told that more than thousand American individuals were radicalized across the country and became ISIS's sympathizers and potential recruits, and 250 American individuals were traveling or attempting to travel to join ISIS in Syria after being radicalized at home. This clearly shows that the biggest threat the U.S is dealing with is domestic terrorism. Among the factors that radicalized these home-grown terrorists in the U.S are the national policies which rise antipathy, such as disagreement with the U.S involvement that perpetuates the bloody Syria conflict and increasing pressure on Muslims in the United States (Gartenstein-Ross 2016, 1-3).

The intense of social media usage plays the vital role in creating home-grown terrorism. The popular phenomenon of this is called online radicalization. Some scholars have explained how social media could influence individuals to turn into terrorist sympathizers and potential recruits. Social media does not have any borders. All people across the borders could easily enjoy the rapid information as well as the long-distant communication. An individual could potentially become radicalized when he is overexposed to the extremist content for the long period of time. The brutal and extreme content he watches frequently, like beheading execution and self-bombing operation, reduces his sense of fear, which results in his readiness to act like those in the content. Moreover, the social media also allows an individual to watch the pressure, torture, and humanitarian calamity being undergone by his fellow community members that, with planned and structured propaganda, triggered anger and antipathy against the 
oppressor and leads to radicalization. Based on this argument, the social media's exposure of the U.S aggressiveness and coercive policy implementation towards Muslims in the Middle East has contributed to radicalize American Muslim individuals itself. Furthermore, the availability of chat online space for social media users is the next factor leading individuals to radicalization. Through chat online application, the terrorists may easily influence an individual by sharing their view on terror justification without being tracked by social monitoring. For the least-radicalized man, the online chat in secret with the fellow extremists will grant him 'silent' support on his view, and at the end, lead him to be more radicalized than before (Bipartisan Policy Center 2012, 17-18).

Many case studies in the U.S. demonstrate how online radicalization contribute to home-grown terrorism. Online radicalization has started since quite long time, precisely when Al Qaeda was still the leading group. In Al-Qaeda's era, five men from northern Virginia were arrested in December 2009 for supporting terrorism activities. They were radicalized after simultaneously watching Taliban's propaganda on YouTube. Then a man called Major Nidal Hasan shot the U.S. army base in Texas in 2009, killing 13 and injuring 29. He was radicalized after being actively engaged to social media activities with terrorist group. He was also reported to make contact with Anwar Al Awlaki, the pioneer of online radicalization, to tell him his respect and ask for attack permission. In 2011, A young man aged 21, Arid Uka, killed two U.S soldiers after watching the online video of Muslim women being raped by the U.S soldiers. This man is also linked to Facebook page which contained many extremist websites (Bipartisan Policy Center 2012, 19-20). The unforgettable bombing in Boston Marathon in 2013 by two brothers, Tsarnaev and Tamerlan, is the next proof of online radicalization. These two young men accessed many online Jihadi magazines from the internet and often watched Anwar Al Awlaaki's speech, as could be tracked from their history of online video search. Tsarnaev who remained alive, told that the online magazine had inspired him and his brother to defend their religion and nation. These two young men also learned how to make a bomb from kitchen tools based on the magazine's simple instruction (Bloom 2018).

ISIS adopted the similar way that its predecessor used to radicalize people across borders. Moreover, there is no terrorist group that utilizes social media as advanced and intensive as ISIS already does to set global propaganda. Its members are active in almost all currently most-used social media platforms, such Twitter, Facebook, Telegram, Ask.fm., WhatsApp, and Skype. ISIS has displayed the crazy militancy in social media account possession. One example of this is 40.000 Twitter accounts belonging to ISIS alone with 2.000 of them were in English. It also published the gradually-issued online magazine called Dabiq - now turning Amaq. The massive social media usage has enabled ISIS to trigger home-grown radicalization. It also helped those who want to travel to Syria and coordinated the series of homeland attacks (Jones et al. 2017, 181182). With all this social media power, ISIS has inspired its "made-in-the-U.S fighters" to launch several lethal attacks within the U.S borders, such as; Manhattan's truck incident killing eight on October 2017, Colorado's shooting incident killing a transit guard on January 2017, Pulse nightclub mass shooting incident killing 49 on June 2016, California's mass shooting incident on December 2015 killing 14, Oklahoma's beheading incident on September 2014, and Washington's incident killing four from April to June 2014. Besides, there have also been 12 non-lethal attacks associated with ISIS since 2014. Both lethal and non-lethal attackers have something in common; they never travel to Syria nor they get trained abroad. They were insiders who got inspired by ISIS (Haltiwanger 2017). 


\section{The U.S. Strategy to Counter Domestic Terrorism}

In order to pressure the number of domestic terrorist attacks and perpetrators, the U.S. just released the most updated set of National counter-terrorism strategies in October 2018. The strategy combines coercive and soft approach to create balance and ensure the greater success. Coercive approach is kind of activities by most powerful actor who uses its power to constrain and disrupt enemy's possibility for action by putting pressure on their will or simply interdicting and disabling them (Anderson $2010,1)$. To coercively combat domestic terrorism, the U.S. will continue to pursue, track, and hunt down the known or suspected terrorist networks - leaders, members, and whoever affiliated with threatening terrorist groups - to the sources through use of force; military or law enforcement operation, before they make a move. This effort will be conducted based on all integrated source of information available for the officers. As the global leader of war on terror, the U.S. will also continue to enforce military and intelligence operation, as well as impose financial sanctions to stop the funding of terrorist activities. Furthermore, the U.S. will also continue to use law of armed conflict detention in Guantanamo Cuba for information gathering. The use of force in domestic and international realm will be coordinated, considering the terrorist networks were smartly coordinating their moves across borders (National Strategy for Counterterrorism of the U.S 2018, 13-14).

The U.S. is trying to incorporate soft approach into its national strategies. Soft approach - or soft power approach - derives from Nye's thought, saying that it was used as the supplement and extension of hard power or coercive ideology identical to neo-realism theory. Nye argued that soft power is an ability to achieve a goal through attraction, making others attracted to follow us, instead of violence; using culture and idea, instead of sanction (Lin and Hongtao 2017, 70). The realization in the U.S. national strategy is the creation of counter radicalization and recruitment program. The U.S. government believes its inclusion is important to stop the neverending battle the U.S. has experienced for 17 years for depending solely on coerciveterrorism approach (National Strategy for Counterterrorism of the U.S 2018, 21). All this time, terrorism keeps growing because radicalization keeps happening. So, counter radicalization and recruitment program is aimed to counter domestic radicalization process basically with three measures; prevention, deradicalization, and post-radicalization (disengagement). Prevention means preventing individuals from being exposed to radical contents in the first place, so that they will not be pulled into the axis of radicalization. Deradicalization means the way to remove radical ideology a belief from radicalized individuals. Whereas post-radicalization aims to disengage the individuals from joining the terrorist groups and getting involved in terrorist activities again, in other words, allowing them to reintegrate into normal society (Vidino 2010, 2-3).

The United States seeks to win the war with idea by combating violent extremist ideologies, so an individual could be prevented from becoming more radicalized and falling off into terrorism path. The United States is attempting to convince that their claims were false and bad solution. Considering that it is easier today for the terrorist to radicalize and recruit individuals online, the U.S. will continue to counter the online terrorist ideologies with the online program it has already possessed (National Strategy for Counterterrorism of the U.S 2018, 21-22). The online program was the part of Counter Violent Extremism (CVE) agenda focusing on composing countermessaging efforts (Mitchell 2016, 107). However, the United States needs to evaluate the outcomes and any other acts that might hinder the program from running as expected. Sometimes, the U.S image displayed in the program is contradicting with the reality. The United States displays an image of peace-lover country while actively get involved in the Middle East bombings. ISIS smartly used this gap opportunity to 
counter-attack the U.S messaging by labelling it as hypocritical country (UNESCO 2017, 37). Furthermore, the U.S. is now willing to cooperate with religious leaders, NGO, and other local stakeholders to win this war of idea, things that the U.S. ignored prior to 2016 (National Strategy for Counterterrorism of the U.S 2018, 21). In addition to preventive measure, the U.S. will also apply; isolating terrorist from sources of support, modernizing counter-terrorism tools like border screening and vetting system, integrating related authorities, protecting infrastructure, and enhancing national preparedness (National Strategy for Counterterrorism of the U.S 2018, 5).

Deradicalization measure might be the new focus of the U.S. government starting from this year. However, this step was in fact ever attempted by one of the U.S. NGOs two years ago. Heartland Democracy NGO, along with Judge Michael Davis of Minneapolis, has ever tried to deradicalize a terrorist suspect by adopting European Exit Program. They invited the European experts to train local staff and placed the terrorist suspect in a house where he could be monitored and rehabilitated by a moderate mentor to remove his radical thoughts. However, the U.S government did not take any glance at this effort nor it offered support at the time (Mitchel 2016, 108). This is because there was skepticism around the U.S. officials on the success of deradicalization measure, even though some others slowly started to trust it after seeing various best practices (Mitchel 2016, 104). Today in its draft of national strategy, the U.S. government will conduct prison staff training and rehabilitation, despite the lack of further concrete explanations. In this case, engaging with local NGOs and moderate clerics as well as international partners to succeed deradicalization measure was the good option available for the U.S. government. Moreover, the U.S. government also starts to focus on post-radicalization measure to help the former terrorist detainees to reintegrate into their societies (National Strategy for Counterterrorism of the U.S 2018, 22). There were no best practices of this measure so far. Yet, the U.S. government stated it would cooperate with foreign partners to fulfill it.

In realm of deradicalization and post-radicalization measures, the U.S. could learn from and cooperate with Indonesia to obtain the best practices the U.S. seemed interested to. The U.S government through its Assistant to the US President for Homeland Security and Counterterrorism, Thomas P. Bossert, has invited Indonesia's National Agency for Combating Terrorism (BNPT) to a Washington meeting and questioned Indonesia's counter-terrorism strategies. Bossert was told about the importance of balancing hard and soft approach and the success stories of Indonesia's implementation of deradicalization and post-radicalization measures. Indonesia government has successfully pressured the number of terrorists. The head of BNPT, Suhardi Alius, claimed that of 560 former terrorists who were ever detained in total, it's only three of them who were back to terrorism path, accounting for $99,4 \%$ of them successfully escaping terrorism path. Many parties were involved in fulfilling the measures, including the former terrorists who can give counter-narratives to their former community-mates (BNPT 2017). This number shows the big contribution of deradicalization and post-radicalization measures in diminishing domestic terrorism in Indonesia, regardless of other kind of counter-terrorism efforts.

In deradicalization measure, BNPT rehabilitates the terrorist detainees to remove extreme ideology out of their mind. This is based on the belief that they once had normal mindset, got radicalized, and could be normalized again. BNPT assigns certified moderate clerics to preach detainees about peaceful religious teaching, inclusiveness, tolerance, and importance of nationality pride. Meanwhile, Psychological experts will conduct mental healing and rehabilitation (Soleh et al. 2018, 97). Simultaneous and continuous efforts will expect detainees to leave their radical thoughts and stop radicalizing other prisoners. Deradicalization measure would never succeed unless 
being completed by the next measure, which is post-radicalization. Indonesia's postradicalization aims disengage the former terrorists from their former communities by helping their after-prison life, an important key to reintegrate with normal society. BNPT was allocating specific budget to assist the former terrorist to make an afterprison life by directing them to an entrepreneurship program after the release. Entrepreneurship program is suitable exertion considering the former terrorists hardly seek for a job due to their criminal record, while they have to meet their daily economic needs. BNPT engaged with local NGOs. Take YLP for this case. It was established by the former terrorist of Jamaah Islamiyah, Ali Fauzi. They collaborated with BNPT to help the former terrorists seeking to run their own entrepreneurship by providing them supportive facilities. Regarding what kind of facility, they will get is all suited with each business interest. One interesting thing is the fact that YLP's founder is the former terrorist attracts the fellow former terrorists - due to psychologically intimacy factor - to join the entrepreneurship program. Running a busy and profitable business cast off away radical path (Soleh et al. 2018, 149-152).

Providing economic empowerment for the former terrorists was important part of post-radicalization measure. At the moment when they are jobless, they might be reembraced by the terrorists and returning to radical path. The availability of job or government's economic support may hinder them to return to the axis of terrorism or even to think of it. This was also to convince them that the country was ready to support them as citizens. The correlation between economic empowerment and terrorism limitation efforts has ever been in Barrack Obama's concern several years ago in his capacity as the U.S. president. In his presidential speech before the U.N General Assembly in 2014, he stated the U.S government would expand the program to support entrepreneurship because that would be great investment to create an antidote to violence. He described how many jobless youths in the Middle East and Africa were drawn into terrorism as they were frustrated with the unemployment situation (Koltai 2014). It is well-said and correct, only if Obama truly means it. But the fact is the initial skepticism among the U.S. officials on how this counter-radicalization would succeed has hampered the implementation of economic empowerment as the part of post-radicalization measure, as Obama once believed.

\section{Controversial Travel Ban Policy}

Just before the national counter-terrorism strategy was introduced to the public in October 2018, the U.S. current president, Donald Trump, has earlier introduced a controversial preventive approach called "travel ban policy" in 2017. Travel ban policy is preventive action aiming to, as Donald Trump insisted, secure the U.S by impeding the terrorist groups and their influence from entering the U.S. He had a tagline to justify the policy: "Making America safe is my number one priority." This travel ban policy is sentenced to several countries, mostly from the Middle East, namely Syria, Iran, Libya, Yemen, Somalia, North Korea, and Venezuela. All citizens of the countries mentioned above are banned from entering the U.S., many criticized it as the ban on Muslims since five of seven banned countries are inhabited by Muslim majorities. However, Trump quickly denies that he has no intention against Muslims. He claimed that he only wanted to protect his country after successfully suppressing terrorist groups in the Middle East and watching the growth of domestic terrorism (BBC 2017). After the long debate in the U.S. domestic realm which was even leading to American's mass protest against the policy at the airport, it was officially upheld by Supreme Court in 
June 2018 and obviously becomes the part of the U.S. national strategy (Smit \& Sabur 2018).

Trump's ban policy is not really popular despite his claim for national security. Not only it leads to domestic mass protests and critiques, but also pulls out worldwide concerns. Iran, Sudan, and Yemen are among the banned countries that voice out the protest of disagreement towards the policy and call it insulting discrimination. The Muslim-majority countries not affected by the ban remain in silence, except for Turkey and Pakistan which also respond by pointing out refusal. The two countries have commitment in welcoming the refugees and emphasize Muslims are the real victim of terrorism and the presence of this ban would just make it worse. The popularity of this policy is more challenged when the U.S allies, namely Great Britain, France, Germany, and Canada also show disrespect, blaming the United States of not complying with International cooperation and commitments on refugees (Ansari 2017). Many critics say the policy is the bad choice and it would be counterproductive to the set of National strategies the United States has just arranged. The policy was rejected for a few reasons, first, it is partially off target. To understand this, we need to take a closer look to the list of the banned countries. Saudi Arabia, Egypt, Pakistan, Bangladesh, India, and Kyrgyzstan (some others may exist) as the countries of origin for American immigrants carrying out a few terrorist activities in the U.S homeland are not in the ban list (BBC 2018). Meanwhile Iran, North Korea, and Venezuela which are never demonstrated to be the countries of origin for the terrorists in the U.S suffer the ban instead. This triggers a question; is it fair to punish people for things they never do? Moreover, it seems Trump fails to identify the main cause of domestic terrorism - as pointed out before - which is not the foreign terrorists who are sneaking into borders, but the terrorists who grew and got radicalized within the U.S. borders.

Second, the travel ban policy continuously creates new trouble for society life. It undeniably affects the lives of many people considering the fact that the U.S is people's main destination for various reasons. According to immigrant advocacy group, the total number of people affected by this travel ban policy could be more than 135 million, by which approximately 80 million come from five Muslim-majority countries of the ban list. Iran is the reported to be the most suffering country due to this ban. Despite hostile relations to the United States, Many Iranians have relatives residing in the U.S and frequently make a visit for family gathering. The total number of IranianAmerican citizens is also huge, which is reportedly more than one million. The travel ban policy affects the students as well. Iran is still the most affected in this sector since it sends more students to the United States if compared to the other banned countries do. At Stanford University for example, Iranian frequently accounts for $10 \%$ of Ph.D. candidates in engineering. Following travel ban policy, there is no single Iranian that will study there this year, which absolutely affects the university's income and reputation. This also happens to other Iranian students who have already received an offer from the U.S universities, yet finally decided to look for another university option in another country (Gladston \& Sugiyama 2018).

The travel ban policy also increases the domestic problem for influencing the education environments. In a survey conducted to measure the American high school student reaction to the travel ban policy, about $36 \%$ of all interviewed teachers reported that at least 1 of their 10 students' express anxiety toward Trump's travel ban policy and his anti-immigrant rhetoric. This happens in both Predominantly White (PW) schools and Predominantly Students of Color (PSC) schools. A few stories of student anxiety and distress convince us more about the policy's impact. A teacher in Texas, Justin Grayson, told that one if his student, from immigrant's family, cried in the classroom when discussing about the policy. He cried because he had no clue whether he would be able to see his mother coming back again to the U.S. The similar story was shared 
by a teacher in Jake Norris school of Delaware. Its talented and smart student namely Amina experienced behavioral change after learning about the policy. She was once the girl with high sense of humor and high dedication for studies. She was suddenly depressed when she realized that she would not be able to see some people again. She became more vulnerable as well with all fears of being displaced from home if her father did things wrong. Amina's change could be clearly viewed from her body language and facial expression (Rogers 2017, 8-9). Thus, this coercive policy was trying to separate between family members that would totally harm the youth psychology.

Third, travel ban policy would trigger hatred and endanger the U.S security. Even though Trump has insisted that this policy is not Muslim ban policy, but perception of Muslims being discriminated was already disseminated across the world's society. Comments of refusal from the various critics and government officials of the other countries seemed to support and justify such perception. Fitzgerald and Cook Martin thought that the U.S is now putting his relationship with Muslim community in danger. They suggested that such policy is irritating both legally and morally. They added that history should have taught the United States a lesson that such discriminating policy might threaten national security. Before the World War II broke out, the United States banned Japanese immigrants from entering the U.S due to racial reasons. The later finding then showed that the exclusion of Japanese immigrants from entry permission fueled Japanese's hatred and raised their motivation to confront against the U.S. for political purposes. Japan created propaganda by labelling the U.S as the most racist nation of the planet to gain support. Another story is the National Security Entry-Exit Registration System (NSEERS) applied by the U.S on Muslim immigrants who were residing in the U.S. NSEERS obligated them to register and detained around 1000 of them. This angered the government of the Muslim countries, stating that the U.S could not indiscriminately detain those who were not related to any terrorist group. The discrimination and stigmatization will hardly keep the U.S allies so close, on the contrary, create the new enemies (Fitzgerald and Martin 2017).

The similar tone derives from the former director of National Intelligence, James R. Clapper, the former senior director for Counter-terrorism, Joshua A. Geltzer, and the former director of the National Counter-terrorism Center, Matthew G. Olsen. These guys were experienced national security officials running counter-terrorism effort in the U.S. homeland. They argued that they have been struggling to stop terrorism since long ago, yet Trump's travel ban policy was going to fuel it. They deemed it counterproductive, making the U.S. security more vulnerable rather than less. An argument that backed up their stances was the principle that effective counter-terrorism should respond to the real threats and real intelligence about threats. Meanwhile, Trump's travel ban policy was not decided based on the real threats nor intelligences. This does make sense why travel ban policy is off target, which means targeting the random countries that are not basically the countries of origin for the terrorist perpetrators, while allowing the certain countries of origin which their citizens were clearly responsible for terrorist attacks. Travel ban policy is claimed unnecessary. The former officials stressed the rigid vetting system for particular suspected travelers have already existed and greatly succeeded in tracking terrorists in the last few years. Most importantly, it was based on real intelligence and law enforcement track-record information, instead of where he/she came from. They added banning people just because they were coming from certain regions was discriminatory act violating American inclusive values. Securing border is a must, yet inappropriate manners will just make it worse (Clapper et al. 2018)

\section{Conclusion}


The U.S will be always in the frontline of war on terror. Various strategies have been attempted to counter the so-called world's big threat both internationally and domestically. Since the U.S. is very active in pursuing the terrorists to the source in the Middle East - even inviting the other countries to join the move - the terrorist groups shifted their strategies to call for a sporadic attack to the U.S. homeland and elsewhere, marking the rise of new problem related to terrorism issue. In the last four years, the number of domestic terrorisms in the Western lands' increases. The attacks were carried out mostly individuals who got radicalized within the U.S. borders, once again, indicating that it was not the foreign terrorists sneaking into borders the U.S. government needs to keep on guard. Responding to the new issue, The U.S. government updated its national strategy by combining coercive and soft approach in its implementation. The inclusion of soft approach in the strategy was deemed necessary by the U.S. government, because over the last 17 years, the U.S. depended more on the coercive approach that it faced the never-ending battles. Moreover, after viewing many best practices conducted by partner countries, the U.S. was convinced about the inclusion and prepared to cooperate with its international partners. The inclusion was expected to stop, otherwise, diminishing such never-ending battles making the U.S. safer than it was.

Despite a set of promising national strategy, President Donald Trump issued a travel ban policy which was deemed controversial, counterproductive, and unnecessary. The policy was imposed on several countries, mostly Muslim countries, that functioned to prevent the foreign terrorists to sneak into the U.S borders due to the increasing number of terrorists' attacks within the U.S borders and anxiety of ISIS's revenge and call for Western countries attack. The policy has entered into force after the long debate. However, the policy fails to meet its objective and even create the contradictory outcome against society, education, and the U.S. national security. This is because Trump fails to identify the real causes, then apply inappropriate policy despite being legal. Travel ban policy might be effective if most terrorist attacks occurring in the U.S. homeland were caused by the foreign terrorists coming from the banned countries and sneaking into the U.S borders. In fact, the attacks were mostly committed by American citizens radicalized at home, a concept called home-grown terrorism. Moreover, the fact that this policy is off target - imposed to random countries without deepening intelligence and information - led to "discriminatory" assumptions which violating American values.

\section{References}

\section{Book and Chapter in Book}

Sholeh, Badrus, et al., 2018. Ekonomi Kaum Muda dan Kebijakan Kontraterorisme. Jakarta: Pustaka Belajar.

\section{Journal and Online Journal}

Anderson, Scott A. "The Enforcement Approach to Coercion", Journal of Ethics and Social Philosophy, October, 5(1): 1-31. 
Jones, Seth. G, et al., 2017. "Rolling Back the Islamic States", RAND Corporation: 3-233.

Katzman, Kenneth and Clayton Thomas, 2017. “Afghanistan: Post-Taliban Governance, Security, and U.S Policy”, Congressional Research Service, December: 1-74.

Lin, Li, and Leng Hongtao, 2017. “Joseph Nye’s Soft Power Theory and Its Revelation Towards Ideological and Political Education", Humanities and Social Science, April, 5(2): 69-74.

Minteh, Binneh, 2014. "Home-grown Terrorism in the United States (US): Causes, Affiliations, and Policy Implications", ResearchGate, March: 1-28.

Mitchell, Stefanie, 2016. "Deradicalization: Using Triggers for the Development of US Program", Journal for Deradicalization, Winter, (9): 101-125.

Rogers, John, 2017. "Teaching and Learning in the Age of Trump: Increasing Stress and Hostility in America's High Schools", Creative Common Attribution, October: $1-40$.

\section{Online Article}

Ansari, Azadeh, et al., 2017. "World Leaders React to Trump's Travel Ban.” [online]. in https://edition.cnn.com/2017/o1/30/politics/trump-travel-ban-world-reaction/ index.html [accessed 23 September 2018].

BBC, 2017. “Trump's US Travel Ban: What's the Full Story?” [online]. in https://www. bbc.co.uk/newsround/38794001 [accessed 22 September 2018].

BBC, 2018. “Trump Travel Ban: What Does This Ruling Mean?”. [online]. in https:// www.bbc.com/news/world-us-canada-39044403 [accessed 23 September 2018].

Bloom, Mia, 2018. "Since Boston Bombing, Terrorists are Using New Social Media to Inspire Potential Attackers." [online]. in https://theconversation.com/sinceboston-bombing-terrorists-are-using-new-social-media-to-inspire-potentialattackers-94944 [accessed 29 September 2018].

BNPT, 2017. "Amerika Ingin Belajar Masalah Penanggulangan Terorisme dari Indonesia." [online]. in https://www.bnpt.go.id/amerika-ingin-belajar-masalahpenanggulangan-terorisme-dari-indonesia.html [accessed 1 October 2018].

Clapper, James R, et al., 2018. "We've Worked on Stopping Terrorism. Trump's Travel Ban Fuels It." [online]. in https://edition.cnn.com/2018/o4/23/opinions/trumptravel-ban-fuels-terrorism-clapper-geltzer-olsen/index.html [accessed 31 October 2018].

CNN, 2018. "Death of Osama Bin Laden Fast Facts" [online]. in https://edition. cnn.com/2013/09/o9/world/death-of-osama-bin-laden-fast-facts/index.html [accessed 22 September 2018].

Constitution on Acts to Prevent Home-grown Terrorism and for Other Purposes, 2007. Washington: The Senate of the United States. [online] in https://www.govtrack.us/ congress/bills/110/hr1955/text [accessed 29 September 2018].

Fitzgerald, David, and David Cook Martin, 2017. “Trump’s Immigration Order is Bad 
Foreign Policy." [online]. in http://theconversation.com/trumps-immigrationorder-is-bad-foreign-policy-72053 [accessed 24 September 2018].

Gladston, Rick, and Satoshi Sugiyama, 2018. “Trump's Travel Ban: How It Works and Who Is Affected." [online]. in https://www.nytimes.com/2018/07/01/world/ americas/travel-ban-trump-how-it-works.html [accessed 23 September 2018].

Haltiwanger, John, 2017. "ISIS in America: How Many Times Has the Islamic States Attacked the U.S.?" [online]. in https://www.newsweek.com/islamic-stateamerica-attacks-744497 [accessed 29 September 2018].

Inserra, David, 2017. "The Diversity Visa is Bad, But the Real Problem in Home-grown Terrorism." [online]. in https://www.heritage.org/immigration/commentary/ the-diversity-visa-bad-the-real-problem-homegrown-terrorism [accessed 22 September 2018].

Koltai, Steven, R, 2014. "Fighting ISIS with Entrepreneurship." [online].in https://www. brookings.edu/blog/fixgov/2014/10/o7/fighting-isis-with-entrepreneurship/ [accessed 6 October 2018].

Levitt, Matthew, 2018. "Trump's Travel Ban Might be Legal, But It's Bad Policy." [online]. in https://foreignpolicy.com/2018/04/25/trumps-travel-ban-might-belegal-but-its-bad-policy/ [accessed 24 September 2018].

Smith, Ben-Riley, and Rozina Sabur. "Supreme Court Uphold Donald Trump's Travel Ban.” [online]. in https://www.telegraph.co.uk/news/2018/o6/26/supreme-courtupholds-donald-trumps-travel-ban/ [accessed 2 November 2018].

\section{Others}

Bipartisan Policy Center, 2012. Countering Online Radicalization in America (Homeland Security Project).

Gartenstein-Ross, David, 2016. "Radicalization in the U.S and the Rise of Terrorism", in a presentation before House Committee on Oversight and Government Reform, 14 September. Washington D.C.

Hendroy, Faruq Arjuna, 2016. Penolakan Iran terhadap Koalisi Amerika Serikat Melawan ISIS di Irak dan Suriah 2014-2015. Undergraduate thesis. Jakarta: International Relations Department, Faculty of Social and Political science, UIN Syarif Hidayatullah Jakarta.

United Nations Educational, Scientific, and Cultural Organization (UNESCO), 2017. Youth and Violent Extremism on Social Media: Mapping the Research.

Vidino, Lorenzo, 2010. Special Report: Counter Radicalization in America. 